\title{
Geotechnical rock mass documentation in the Bátaapáti radioactive waste repository
}

\author{
Ferenc Deák ${ }^{1}$, László Kovács ${ }^{1}$, Balázs Vásárhelyi ${ }^{2 *}$ \\ ${ }^{1}$ RockStudy Ltd., Pécs, Hungary \\ ${ }^{2}$ Department of Structural Engineering, Pollack Mihály Faculty of Engineering, University of Pécs, Pécs, \\ Hungary
}

\begin{abstract}
The geologic, geotechnical and rock mechanical background of the area, which includes an underground cavern system, is very complex. Initially, to describe the rock mass properties, the RMR and Q systems were used, while the rock support system was based solely on the $\mathrm{Q}$ system. Later, during construction of the repository chambers, the GSI system was also introduced in addition to the above-mentioned rock classification methods. The correlation and usage of these three different rock mass classification systems were investigated.

Special methods were used to obtain more accurate tunnel mapping and documentation, which is based on photogrammetry and photo analyzer software.

According to the results, the correlation between the RMR and Q values is independent of the rock type; basically, the same equation can be used for all (differences between experimental error). The GSI intervals also closely follows the same trend as the results of the other two methods.
\end{abstract}

Key words: RMR, Q, GSI, rock mass classification, nuclear waste repository

\section{Introduction}

The program for the final disposal of low and intermediate-level radioactive waste was established by the Paks Nuclear Power Plant (Hungary). Preparation for final disposal of radioactive waste has been carried out as part of a national program since 1993. The Central Nuclear Financial Fund and the Public Limited Company for Radioactive Waste Management (Puram) were established to coor-

\footnotetext{
* Corresponding author; Hollosy S. u. 3, 1126 Budapest, Hungary; Phone: +36 12018 632; Fax: +36 12018 632; E-mail: vasarhelyib@gmail.com

Received: November 15, 2012; accepted: January 8, 2014
} 
dinate organizations and activities for all tasks in connection with nuclear waste treatment. The project began with a geologic screening in order to find the most suitable formation for radioactive waste disposal. The selected potential host rock is a granite complex in the Mórágy Granite Formation in the southwestern part of Hungary, close to the village of Bátaapáti (Balla et al. 2003). The geologic situation is presented in detail by Balla et al. (2008).

As a result of the final report of surface geologic exploration carried out between 2001 and 2003, an subsurface exploration program was initiated in 2005 in parallel with tunnel excavation. The tunnel excavation was carried out by drilling and blasting, with a rate of advance of 1 to 3 meters. Tunneling was preceded by pilot coring, permitting the establishment of geologic and geotechnical predictions. The inclined twin-access tunnels were constructed with $\sim 30 \mathrm{~m}$ centerline spacing, of $1.7 \mathrm{~km}$ length and a $10 \%$ slope. The twin tunnels are connected by eight cross-tunnels (Fig. 1). The inclined access tunnels end at the target elevation of $0 \mathrm{~m}$ above sea level, while the overburden above the repository area is $240-270 \mathrm{~m}$. During the construction of the underground facility, $21 \mathrm{~m}^{2}, 25 \mathrm{~m}^{2}$ and $36 \mathrm{~m}^{2}$ cross-sections were used. In September 2011, two repository chambers, with $96 \mathrm{~m}^{2}$ cross-section (including final lining), were completed (Benkovics et al. 2010). The project will be continued by excavating additional chambers.

The shear strength of the investigated granitic rocks was investigated by Buocz et al. (2010). These results were used for block analysis. In this study the rock mass was assumed to be of homogenous, isotropic, continuous material. This model can be used for design and construction in this area (see Fábián et al. 2007).

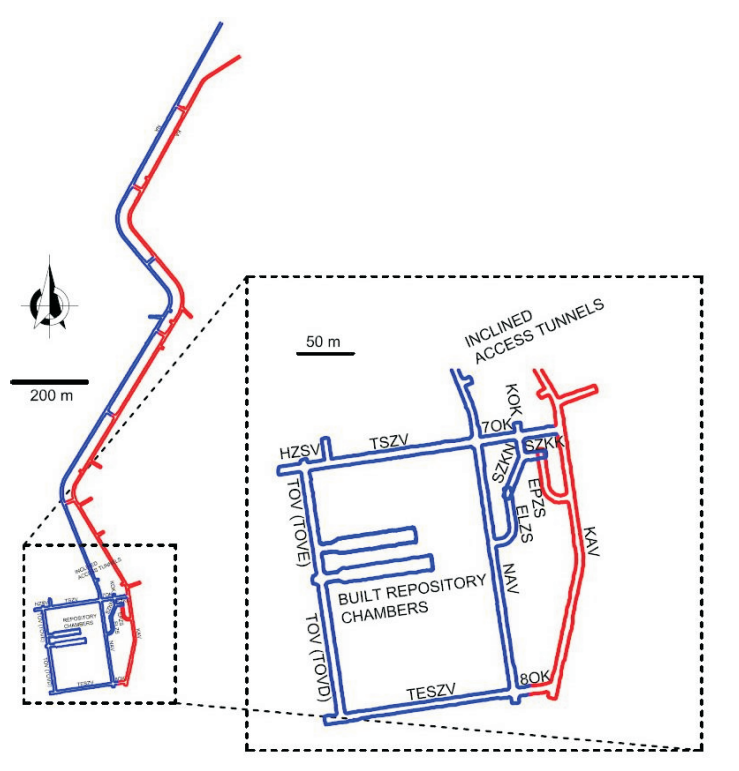

Fig. 1

Schematic view of the National Radioactive Waste Repository at Bátaapáti, Hungary 
The geotechnical results of the tunnel face documentation were statistically analyzed; after each project phase, the results were published in geotechnical reports. Calculated correlation results and conclusions can be used for the further design of the new caverns at Bátaapáti.

\section{Geologic and geotechnical conditions}

The Paleozoic granite is an intruded and displaced batholithic body. The Mecsekalja Belt is located near this area, which is an extended tectonic zone with very complex geologic and geotechnical background (Balla et al. 2003). At shallow depths the tunnels crossed through a completely decomposed, weathered rock mass. The granite is randomly crisscrossed by trachyandesitic and aplitic veins, indicating a lower degree of weathering, followed by tectonically-caused tension joints. Also, at greater depths, the granite is intersected by fault zones, interlaced with about 5 to $10 \mathrm{~m}$-long clay and mixed breccia zones. The rock mass is stochastically fractured with limonite, hematite, chlorite, and carbonate infillings. Some apparent trends can be discovered in the inclined exploratory tunnels, e.g. at the veins the fracturing shows a NE-SW strike with flat dip angles, while the igneous structural set is represented by a NE-SW strike and $65-75^{\circ}$ dip angle.

Geotechnically, four main rock types can be distinguished: monzogranite, monzonite, veins and hybrid rocks. The percentages of these rocks in the test tunnels of the repository area were as follows: monzogranite $62 \%$, monzonite $1 \%$, veins $10 \%$ and hybrid rocks $27 \%$. The two repository chambers were cut through a rock mass which contained mainly monzogranite with aplitic veins and scarce monzonite inclusions.

The design of the entire rock support system of the Bátaapáti Project is based on the Q method. During the excavation of the two inclined access tunnels, five main rock mass categories were determined by the designer on the basis of Q method. In the repository area (horizontal access tunnel system and the chambers) the designer introduced one more rock classification category (Table 1).

In the case using the RMR method the rock mass was integrated in the original five rock classes (Bieniawski 1973). Why were the RMR and Q methods used in

Table 1

$\mathrm{Q}$ rock classes used for the Bátaapáti Project

\begin{tabular}{cc}
\hline $\begin{array}{c}\text { Q values at the inclined } \\
\text { access tunnels }\end{array}$ & $\begin{array}{c}\text { Q values at the } \\
\text { horizontal access tunnels } \\
\text { and repository chambers }\end{array}$ \\
\hline I. $\mathrm{Q}>12.9$ & I. $\mathrm{Q}>10$ \\
II. $12.9-0.6$ & II-A. $10-4$ \\
III. $0.6-0.07$ & II-B. $4-1$ \\
IV. $0.07-0.02$ & III. $1-0.1$ \\
V. $Q<0.02$ & IV. $0.1-0.02$ \\
& V. $\mathrm{Q}<0.02$ \\
\hline
\end{tabular}


parallel from the beginning of excavation? The main reason is the fact that the database defined by surface exploration is based exclusively on the RMR method. Accordingly, knowledge of location-dependent or location-specific correlations between the above-mentioned rock mass classification systems was necessary for predicting rock support and other tunneling conditions.

The rock mass in the inclined access tunnels is mainly described as "Fair rock" (class III); the best rating was in the final section (1,600 to 1,700 tunnel meters) of the inclined access tunnel system, which was cut through a huge monzonite block which was documented as "Good" and "Very good" rock (RMR - classes I and II). It should be noted that Class I is not represented significantly; it was only documented a few times. A general overview regarding the construction of the two repository chambers is shown in Fig. 2.

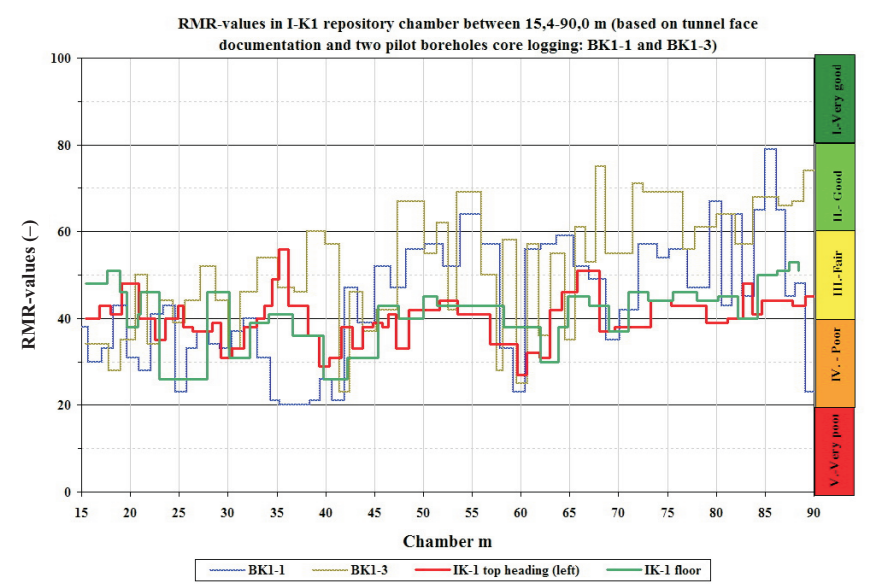

Fig. 2

RMR values for the repository chambers constructed

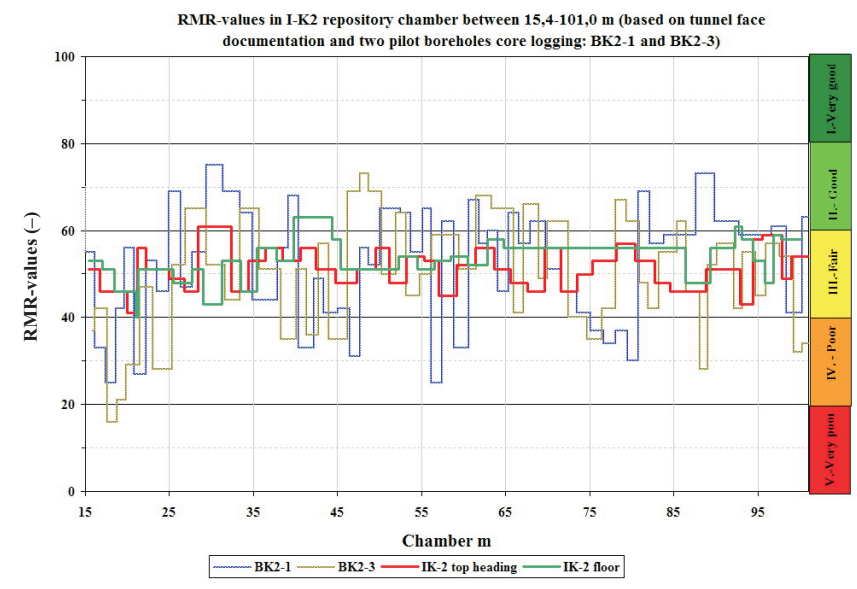


Although the underground cavern system was excavated in fair-quality rock mass, the cavern walls were shotcreted after every blasting advance step. The site geologist was required to carry out tunnel mapping after every drill and blast cycle. The mapping process was divided into two parts:

(1) Photo documentation after the removal of blasted material (during the documentation process, it is forbidden to enter unsupported areas),

(2) Descriptive documentation of the tunnel face after the roof and side walls have been supported by shotcrete.

In the case of each advance step, 100 minutes were provided for photo and descriptive mapping. At the same time, documenting the tunnel was carried out by 2 persons: a geologist (tectonic, mineralogical, hydrogeologic mapping) and an engineering geologist (collecting all parameters for rock classification systems).

As the time interval of each phase was short and the documenting work was unrepeatable due to the shotcrete applied to the walls, it was very important to use a modern, precise system to create $3 \mathrm{D}$ photorealistic models of the rock surfaces of

Fig. 3

Tunnel face documentations of repository chambers with ShapeMetriX3D system (left-right top heading and invert in case of $\mathrm{Q}$ classes: IV,V; top heading and invert in case of $\mathrm{Q}$ classes: I, II-A, II-B, III)

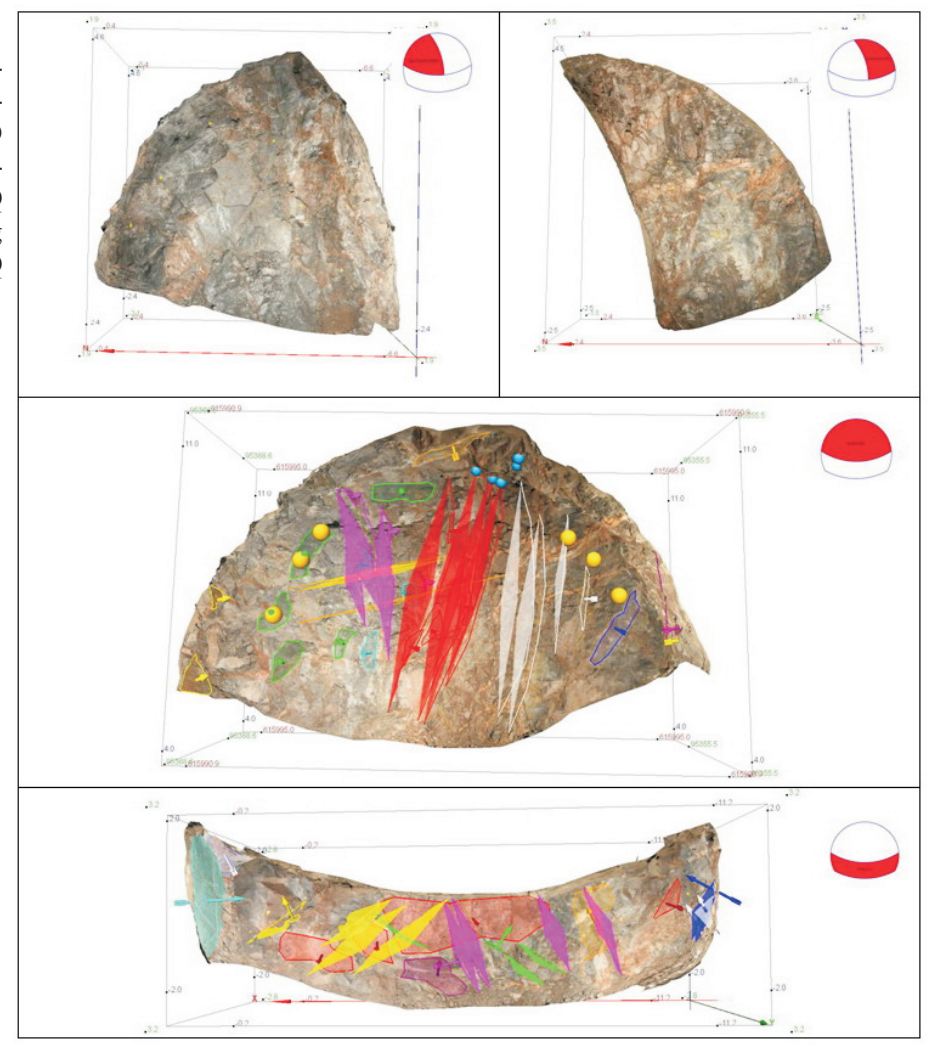


the excavated tunnel walls. For this reason the photogrammetric method was chosen, because it has adequate resolution and quality for the photo-combined 3D models. At the beginning, the JointMetriX3D system and subsequently, in the repository chamber excavation phase, the ShapeMetriX3D system was used (Fig. 3).

Both RMR and Q values were determined for the Bátaapáti access tunnels on the basis of tunnel-face documents (Deák et al. 2006). These two methods are widely used for tunnel design and during the construction phases for determining the span of roof, excavation methods and required supports (for more details about the methods, see Bieniawski 1973, 1976, 1989; Barton et al. 1974; Barton 2002). During the repository chambers excavation phase use of the GSI system began in parallel with the above-mentioned classification systems (for more details, see Hoek 1994, 1998; Marinos and Hoek 2000; Hoek et al. 2005; Marinos et al. 2005). The database currently includes 2,678 tunnel advance documents. In 216 cases the GSI, RMR and Q methods were used simultaneously.

\section{Interrelationship between RMR and $Q$ methods}

Despite some differences between the methods, three important properties - integrated in both the RMR and Q systems - influence the rock mass behavior, i.e. degree of fracturing, discontinuity conditions and groundwater. Up to now several correlations have been published between the RMR and the Q methods. All of these established the logarithmic interrelationship below:

$$
\mathrm{RMR}=a \ln \mathrm{Q}+b
$$

where $a$ and $b$ depend on features of the investigated site. These published values were collected from different tunnels and mining projects from all over the world by Choquet and Hadjigeorgiou (1993) and Singh and Goel (1999). According to these publications, parameters $a$ and $b$ range from 5 to 15 (the average is 9.78) and from 38 to 60.8 (the average is 47.35), respectively. One of the goals of this study was to investigate this relationship [Eq. (1)] in order to establish a correlation between these two material constants.

The published parameters are summarized in Table 2; Fig. 4 illustrates the correlation between $a$ and the ratio $b / a$.

Table 2

Different constants for calculation of RMR value from Q value [Eq. (1)] using the published data of Choquet and Hadjigeorgiou (1993) and Singh and Goel (1999)

\begin{tabular}{cccccccccccc}
\hline \multicolumn{10}{c}{$\mathrm{RMR}=a \ln \mathrm{Q}+b$} \\
\hline$a$ & 5 & 5.4 & 5.9 & 8.7 & 9 & 10 & 10.5 & 12.11 & 12.5 & 13.5 & 15 \\
$b$ & 60.8 & 55.2 & 43 & 38 & 44 & 39 & 41.8 & 50.81 & 55.2 & 43 & 50 \\
\hline
\end{tabular}


Fig. 4

Relationship between parameters $a$ and ratio $b / a$ took from different published data, according to Eq. (1)

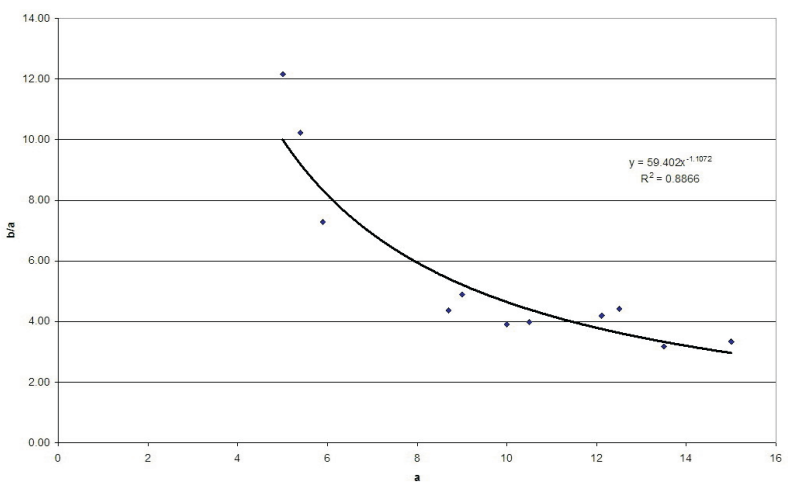

According to Fig. 4 the following connection can be determined:

$$
b=59.402 a^{-0.1012} \text {. }
$$

Bieniawski (1989) suggested the following equation for the relationship between the two different rock mass classification methods:

$$
\mathrm{RMR}=9 \ln \mathrm{Q}+44 .
$$

The constants in Eq. (3) are statistically the average values of various projects. Up to now this is the most widely known transition between the RMR and Q meth-
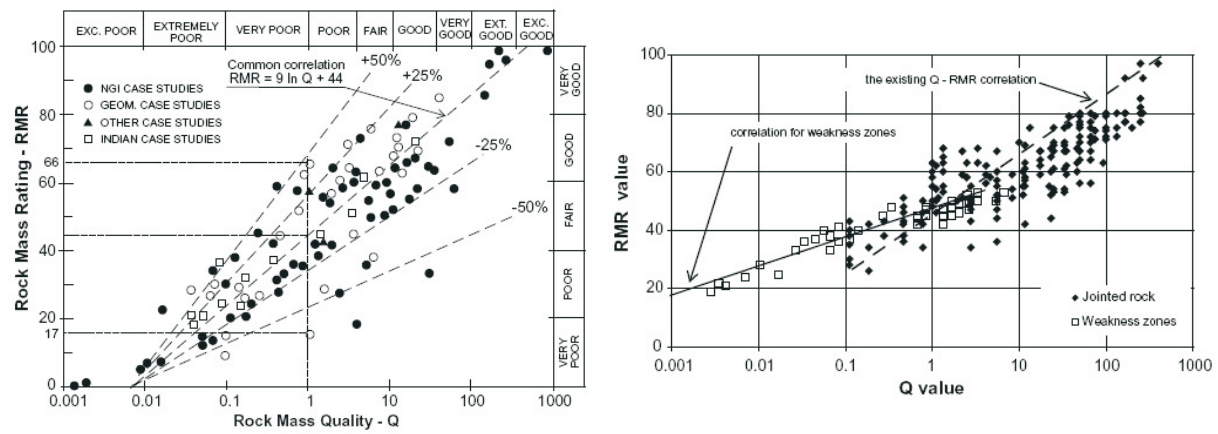

Fig. 5

Correlation between the RMR and Q values according to Bieniawski (1989) (left), using the figure of Palmström (2009) (right). Obviously for $\mathrm{Q}=1$, RMR varies from less than 20 to more than 60 . Note that the $\mathrm{Q}$ system applies logarithmic scale while RMR has a linear one

ods. Recently it was analyzed by Palmström (2009). However, he mentioned that this correlation is a very rough approximation, representing an inaccuracy of $\pm 50 \%$ or higher (see Fig. 4 ). 
According to the definition of the Q value (Barton et al. 1974), in case of $Q<1$ (i.e. poorer rock mass, weakness zone) the rock mass behavior is different from that in case of Q > 1 (jointed rock mass). Thus, Palmström (2009) suggested to have the RMR-Q correlation determined differently for these two rock mass classes, as presented in Fig. 5.

\section{Results from the exploratory tunnels}

Correlation for monzogranite

Most of the data are from the monzogranite rock type. The $\mathrm{Q}$ values lie between 0.01 and 11.2 . The distribution within this range was $16 \%$ between $0.01-0.1,48 \%$ between $0.1-1.0$, and $34 \%$ between 1 and 4 . Only $2 \%$ of tunnel faces were higher than 4 .

According to the calculations the following equations were found for the monzogranite rock type:

$$
\begin{aligned}
& \mathrm{RMR}=8.73 \ln \mathrm{Q}+67(\mathrm{Q}<1)\left(\mathrm{R}^{2}=0.72\right) \\
& \mathrm{RMR}=8.25 \ln \mathrm{Q}+66(\mathrm{Q}<4)\left(\mathrm{R}^{2}=0.72\right) \\
& \mathrm{RMR}=8.10 \ln \mathrm{Q}+66(\mathrm{Q}>4)\left(\mathrm{R}^{2}=0.72\right)
\end{aligned}
$$

Note that the correlation between the two rock mass classification systems was not statistically determinable in the case of $\mathrm{Q}<1$. The differences between the constants are within the limits of statistical error.

\section{Correlation for monzonite}

The 388 measured and calculated Q values were between 0.02 and 9.77. Only eight data points were higher than 4 and 129 (33\%) higher than 1 . The calculated equation is:

$$
\mathrm{RMR}=7.10 \ln \mathrm{Q}+68\left(\mathrm{R}^{2}=0.74\right) .
$$

The difference between Eq. (6) and Eq. (7) is within the limits of statistical error.

According to the results, the correlation between the RMR and Q values is independent of the rock types, i.e. basically the same equation can be used for all types. The next section contains the analysis of the integrated monzogranite and monzonite data set with the result for all investigated rock types.

\section{Results from the entire Bátaapáti underground facility}

It was very important to provide a "straight" equation for the RMR and Q correlation on the basis of continuously updated statistical results. The main reason for 
this was to enable the conversion of RMR core log data of the exploratory boreholes into Q values, because of the Q based rock support system in Bátaapáti. To begin with Eq. (3) had been used, but following the initial summary tunnel report after the first $600 \mathrm{~m}$ advance in each of the inclined access tunnels, the following equation was introduced:

$$
\mathrm{RMR}=7.84 \ln \mathrm{Q}+57.8\left(\mathrm{R}^{2}=0.73\right) .
$$

After analyzing the final data, we found a very closely correlating equation for our location specific formula (Fig. 6):

$$
\mathrm{RMR}=7.94 \ln \mathrm{Q}+60.7\left(\mathrm{R}^{2}=0.76\right) .
$$

The correlation is also suitable for weakness zones in the case of the Mórágy Granite (which covers horizontally a length of $\sim 2 \mathrm{~km}$ and a depth of $\sim 240 \mathrm{~m}$ of the rock mass). The interrelationship between the two rock mass classification methods, in the case of good and very good rock qualities, cannot be evaluated statistically in an appropriate way because of the poor data set of these rock quality. The equation suggested by Bieniawski (1989) [Eq. (3)] could be suitable for these rock classes.

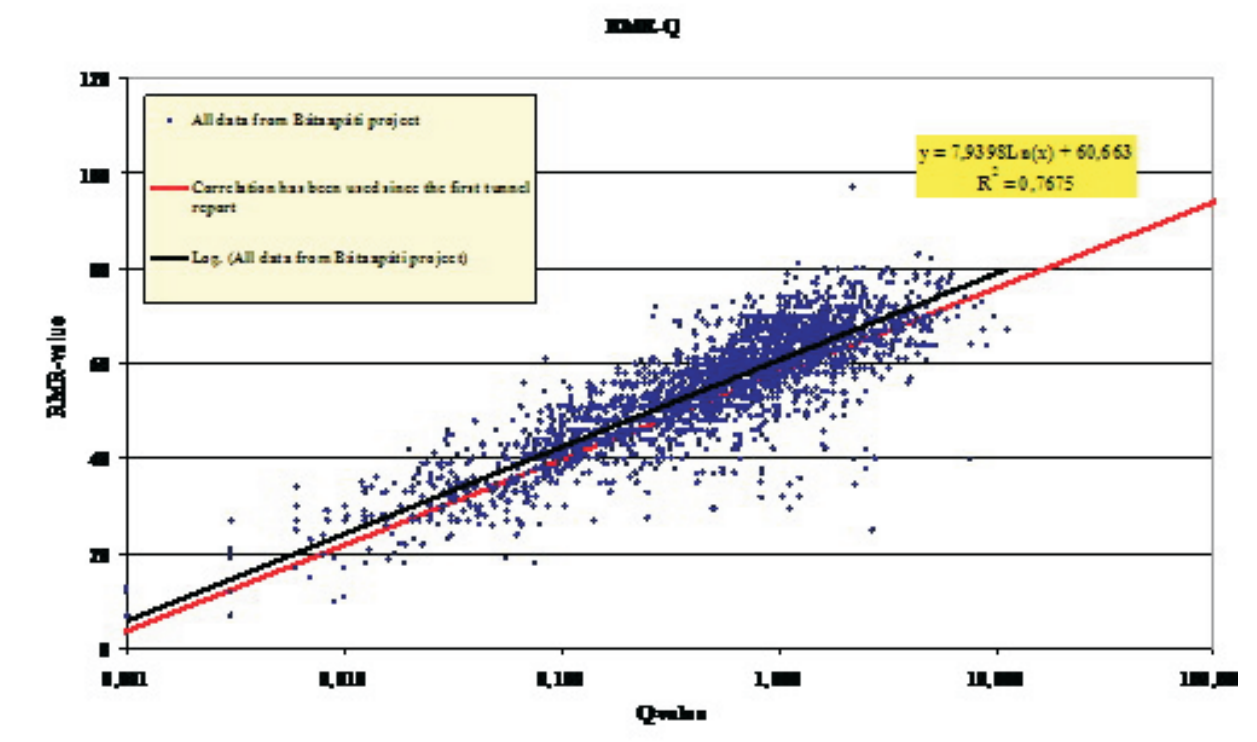

Fig. 6

RMR and Q correlations from Bátaapáti underground facility 


\section{Analyses of the GSI results}

The Geological Strength Index (GSI) has been developed over many years based on field observations and largely on practical experience. Based on the geologic description of the rock mass, it involves two factors (Fig. 7): on the one hand the rock structure (or block size - the GSI matrix arrays), and on the other the surface conditions (joint or block surface - the GSI matrix columns).

The need for practical experience during the classifications involves some subjectivity during the GSI categorization. Hence long-term geologic engineering observations are required for the successful application of the GSI system.

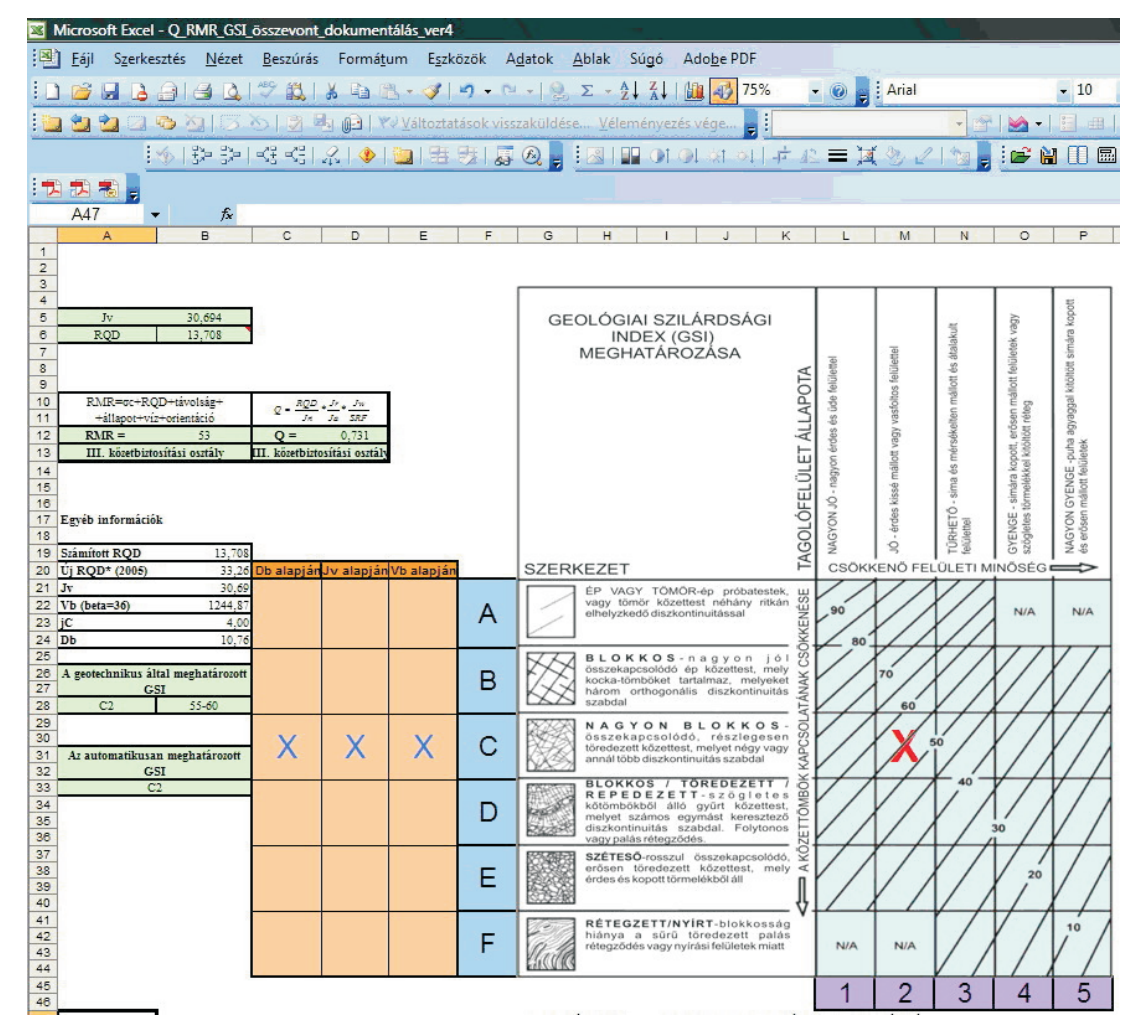

Fig. 7

Results included in the site calculation spreadsheet

In order to avoid mistakes and enhance objectivity of the GSI classification, it was expanded with quantitative determination, by adding measurable quantitative input for the final quantitative output results (details in Cai et al. 2004 and Russo 2009). 
Beside the Q and RMR input, for the quantitative GSI calculation we introduced only one more input parameter into the calculation spreadsheet, namely the joint size and continuity factor $(\mathrm{jL})$ - as applied in RMi characterization (Palmström 2001). To calculate the jC (joint condition factor) we used the following equation:

$$
\mathrm{jC}=\mathrm{jL}(\mathrm{jR} / \mathrm{j} A)
$$

where $\mathrm{jR}$ and $\mathrm{jA}$ are the $\mathrm{Q}$ input parameters (joint roughness and joint alteration).

$\mathrm{The} \mathrm{Vb}$ (block volume) is expressed by the RQD value and $\mathrm{Db}$ (block diameter) from $\mathrm{Vb}$. JC characterizes the columns of the GSI matrix (surface conditions), while $\mathrm{Vb}$ and $\mathrm{Db}$ characterize the arrays (structure) during the quantitative GSI determination.

Automatically, a broader location is defined on the GSI matrix; thus a final range of results was chosen by the site geologist (considering other influences such as appearance of water), together with the matrix position (e.g. C2 55-60; Fig. 7).

The main part of the rock mass around the excavation is a structurally "Very Blocky", interlocked, partially disturbed mass with multi-faceted angular blocks formed by four or more joint sets. Based on the surface conditions there are "Poor", slickensided, highly weathered surfaces with compact coatings or fillings, or angular fragments (Fig. 8).
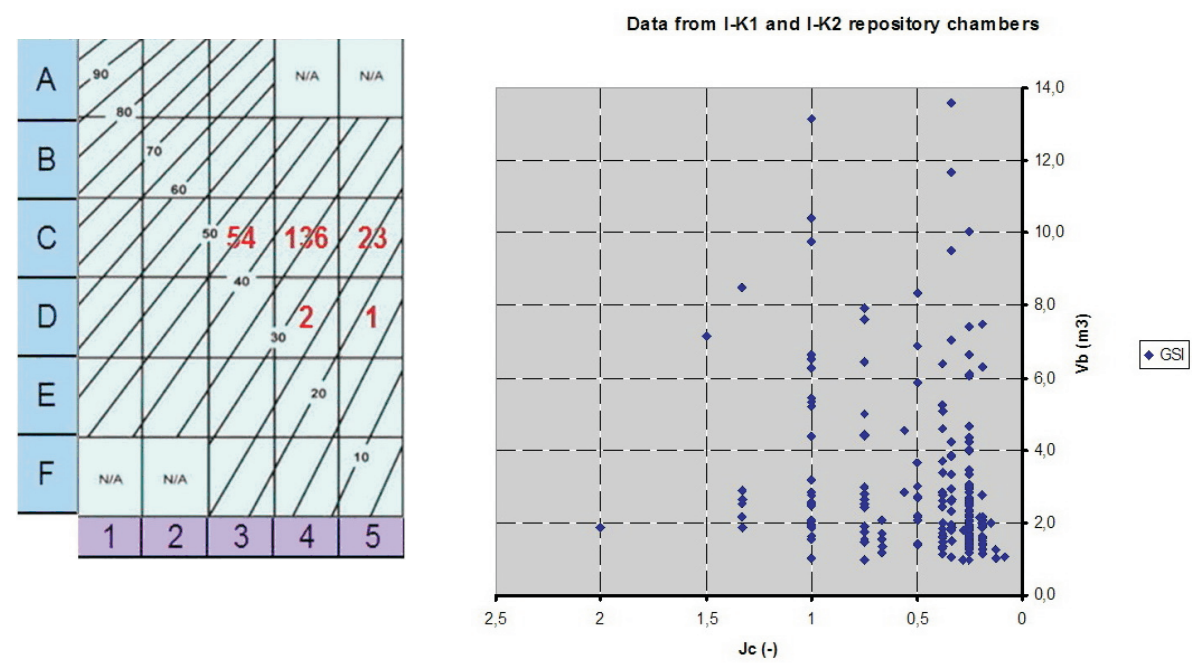

Fig. 8

GSI determination from the repository chamber database (broader confinement - left; and scattered representation - right) 


\section{GSI-RMR and GSI-Q correlations}

Unlike the RMR-Q correlations, poorer correlation coefficients were found in the case of GSI-RMR and GSI-Q interrelationships at the best fits (Fig. 9):

$$
\begin{gathered}
\mathrm{GSI}=15.138 \mathrm{e}^{0,02 * \mathrm{RMR}}\left(\mathrm{R}^{2}=0.68\right) \\
\mathrm{GSI}=5.96 \mathrm{Ln}(\mathrm{Q})+47.85\left(\mathrm{R}^{2}=0.66\right)
\end{gathered}
$$

Upon further investigation we checked the documentation separately. We divided the database into several portions according to the data of the five site geologists who carried out the tunnel mapping.

For all classification systems there are difficulties in observing appropriate jointing characteristics (Palmström 2001, 2006). In the same location, different persons may map the joints differently and can describe different rock mass characteristics. In his paper Palmström outlined a case study including the fact that 17 to 21 joints were mapped by 6 observers along the same scan line; however, in the observers' maps, these joints were shown to exist in different spatial locations. For the RMR and Q system, the joint features, condition of discontinuities (RMR) and Jr, Ja, and especially Jn (Q), in addition to RQD values, could produce mischaracterizations.
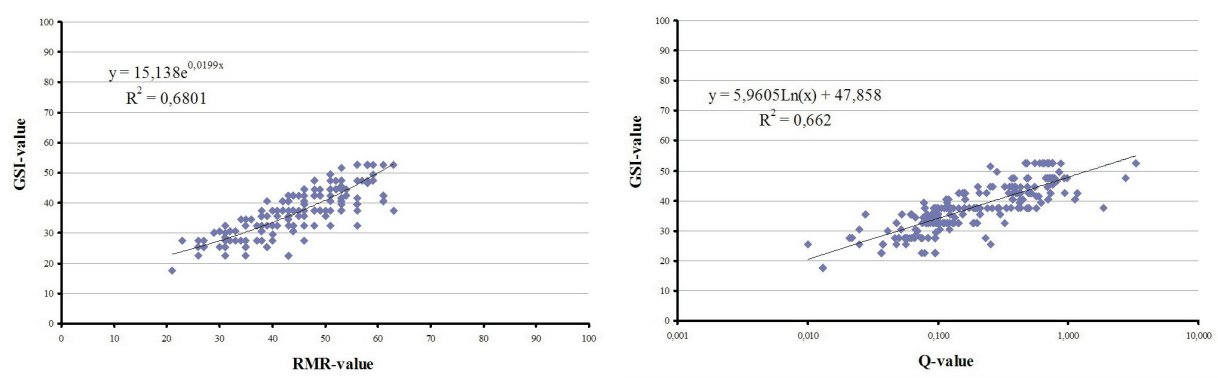

Fig. 9

GSI correlations with RMR and Q values from Bátaapáti I-K1 and I-K2 repository chambers

From the separate analyses of the database it has become evident that several significant differences appeared between the correlations given by the individual tunnel documentations (Fig. 10).

In the case of all rock mass classification systems we have found the best fits in the SG and DF site geologist's databases. For all geologists, Q-RMR correlations are better. In this case, subjectivity might be experienced because these two rock classification methods have been used since the beginning of the project and, in order to avoid running into contradictions, geologists, being aware of the RMR-Q correlation, tend to have the routine habit of "randomly" modifying input parameters of the mentioned methods during the analysis of final results. 
Geotechnical rock mass documentation in the Bátaapáti radioactive waste repository 209

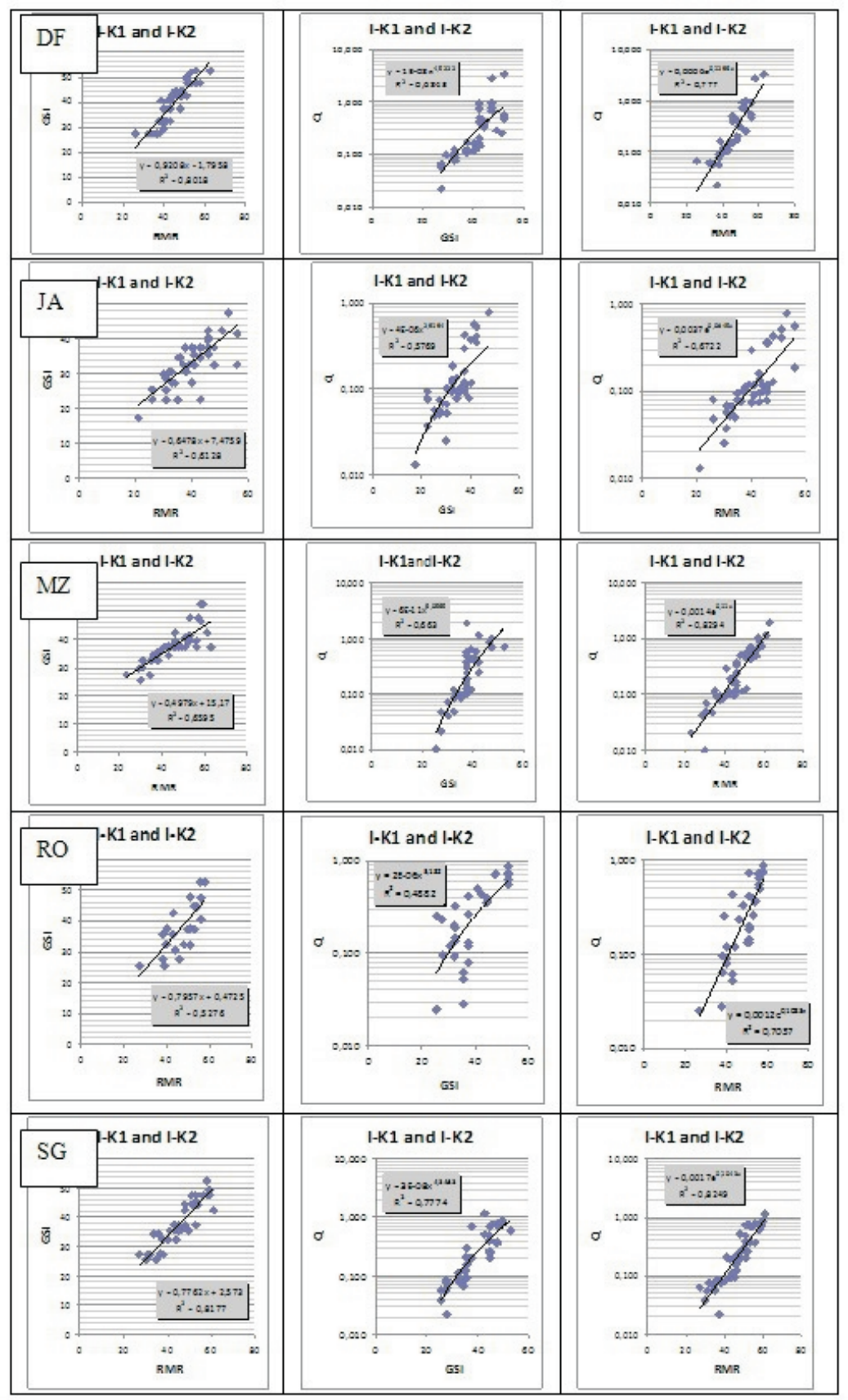

Fig. 10

Correlations based on different site geologists (DF, JA, MZ, RO, SG) documentations 
Low correlation coefficients appear in the case of GSI-RMR and GSI-Q connections because there are contradictions between the RMR conditions of discontinuities (roughness and weathering) and Q inter-block shear strength $(\mathrm{Jr} / \mathrm{Ja})$. Upon solving these contradictions, anomalies could appear during the GSI-RMR interrelationship analyses, when the site geologists have obtained knowledge of the main discontinuity or fracture system orientation. However, they had been using a wrong orientation rating during the RMR calculation.

\section{Conclusions}

Beside the correlations which are frequently encountered in the international scientific literature, it is necessary to create local specific correlations from one's own database to avoid mistakes during design calculations. Our results show apparent deviations between the "Bátaapáti specific" correlations and those mentioned above.

According to the results, correlations between RMR and Q values are independent of the rock types; basically the same equation could be used. The correlation is suitable for weakness zones as well in the case of the Mórágy granite. Probably the widely-used equation [(Eq. (7)] could be suitable in the case of jointed and weathered rock masses, but use of the final equation [Eq. (8)] is suggested for all rock types and masses for the Bátaapáti project. Simultaneous use of three methods, namely RMR, Q and GSI, allows eliminating the contradictions between input parameters of these systems and to create, without error, a real quantitative and objective rock mass characterization. Beside the correlations which are frequently encountered in the international scientific literature, it is necessary to create location-specific ones from one's own databases, in order to avoid errors during design calculations. Our results show apparent deviations between "Bátaapáti specific" correlations and those mentioned above.

\section{References}

Balla Z., G. Albert, G. Chikán, A. Dudko, L. Fodor, M. Forián-Szabó, M. Földvári, L. Gyalog, G. Havas, I. Horváth, Á. Jámbor, M. Kaiser, L. Koloszár, B. Koroknai, P. Kovács-Pálfy, Gy. Maros, I. Marsi, K. Palotás, Zs. Peregi, L.-né Rálisch, Á. Rotárné Szalkai, T. Szőcs, Gy. Tóth, G. Turczi, Zs. Prónay, L. Vértesy, L. Zilahi-Sebess, Galsa A., G. Szongoth, Gy. Mező, P. Molnár, F. Székely, G. Hámos, I. Szűcs, Z. Turger, G. Balogh, G. Jakab, Z. Szalai 2003: Az atomerőmüvi kis és közepes aktivitású radioaktív hulladékok végleges elhelyezésére irányuló program. A felszíni földtani kutatás zárójelentése, Bátaapáti (Üveghuta), 2002-2003, 1-3. kötet (Program for the final disposal of low and intermediate radioactive waste repository. The surface exploration final report at Bátaapáti, Üveghuta). (in Hungarian) - Kézirat, Országos Földtani és Geofizikai Adattár T: 20 914; Magyar Állami Földtani Intézet, Budapest, Tekt. 1102; Bátatom Kft., Budapest, BA-03-156.

Balla, Z., G. Császár, M. Földvári, Z. Gulácsi, L. Gyalog, I. Horváth, M. Kaiser, E. Király, L. Koloszár, B. Koroknai, Á. Magyari, Gy. Maros, I. Marsi, B. Musitz, E. Rálisch, Á. Rotárné Szalkai, T. Szocs, Gy. Tóth, J. Berta, Á. Csapó, G. Csurgó, Z. Gorjánácz, G. Hámos, Z. Hogyor, A. Jakab, I. Molnis, J. Ország, G. Szimoncsics, I. Szamos, G. Szebényi, I. Szucs, Z. Turger, A. Várhegyi, K. Benedek, P. Molbár, I. Szego, Gy. Tungli, A. Madarasi, Sz.E. Mártonné, Zs. Prónay, P. Tildy, G. Szongoth, M. Gacsályi, K. 
Moskó, L. Kovács, P. Mónus, B. Vásárhelyi 2008: A felszín alatti földtani kutatás zárójelentés, 1. kötet. (Summary report of the subsurface geological research, Volume 1) (in Hungarian) - Kézirat, Magyar Állami Földtani Intézet, Budapest, RHK Kht., Paks, RHK-K-082/08.

Barton, N. 1974: A Review of the Shear Strength of Filled Discontinuities. - Norwegian Geotechnical Institute Publications, No. 105. Oslo, pp. 1-30.

Barton, N. 2002: Some new Q-value correlations to assist in site characterization and tunnel design. - Int. J. Rock Mech. \& Mining Sci. 39, pp. 185-216.

Benkovics, I., K. Barabásné Rebró, J. Berta, J. Csicsák, Z. Hogyor, L. Ropoli, G. Szebényi, P. Tamás, P. Tóth, M. Varga, V.R. Miskolczi, F. Vrászlai, F. Takáts, L. Kulcsár, A. Thomas, D. Hersvik, Gy. Németh, A. Lowson 2010: A Bátaapáti Nemzeti Radioaktívhulladék-tároló feltáró vágatai térkiképzése. Kiviteli terv II. ütem 3. szakasz. I-K1 és I-K2 tárolókamra (Bátaapáti National Radioactive Waste Repository excavation of the access tunnels. Design plan, $2^{\text {nd }}$ stage, $3^{\text {rd }}$ part, repository chambers 1-K1 and 1-K2) (in Hungarian) - Kézirat, 2010. szeptember. RHK Kft. Adattára. RHK-K-123C/09.

Bieniawski, Z.T. 1973: Engineering classification of jointed rock masses. - The Civil Engineer in South Africa, 15(12), pp. 335-343.

Bieniawski, Z.T. 1976: Rock mass classifications in rock engineering. - Procs Int. Symp. on Exploration for Rock Engng, A.A. Balkema, Johannesburg, Vol. 1, pp. 97-106.

Bieniawski, Z.T. 1989: Engineering Rock Mass Classifications. John Wiley and Sons, PA.

Buocz, I., N. Rozgonyi-Boissinot, P. Görög, Á. Török 2010: Laboratory determination of direct shear strength of granitoid rocks; examples from the host rock of the nuclear waste storage facility of Bátaapáti (Hungary). - Central European Geology, 53(4), 405-417.

Cai, M., P.K. Kaiser, H. Uno, Y. Tasaka, M. Minami 2004: Estimation of rock mass deformation modulus and strength of jointed hard rock masses using GSI system. - Int. J. Rock Mech. Min. Sci. 41, pp. 3-19.

Choquet, P., J. Hadjigeorgiou 1993: Design of Support for Underground Excavations. - In: Hudson, J. (Ed.), Comprehensive Rock Engineering, Vol. 4, Chapter 12, pp. 313-348.

Deák, F., I. Molnos, L. Kovács, B. Vásárhelyi 2006: Bátaapáti radioaktív hulladéktároló építése Geotechnikai vágatdokumentálás (Tunnel construction in Bátaapáti - Geotechnical face documentation) (in Hungarian). - Mélyépítés, 4(17), pp. 7-13.

Fábián M., P.K. Bakainé, Zs. Tari, J. Bognár, I. Brandmüller, Z. Buócz, V. Keszerice, L. Kovács, L. Livo, Cs. Mátrai, I. Molnár, P. Molnár, G. Szebényi, B. Vásárhelyi, O. Viczencz 2007: A Bátaapátiban létesülő Nemzeti Radioaktívhulladék-tároló felszín alatti létesítményeinek műszaki tervdokumentációja (Technical Documentation of the Subsurface Works of the Bátaapáti National Radioactive Waste Disposal Site) (in Hungarian). - 9. melléklet, RHK Kft., RHK-K-055A/07.

Hoek, E. 1994: Support of rock masses. - ISRM News Journal, 2(2), pp. 4-16.

Hoek, E. 1998: Reliability of Hoek-Brown estimates of rock mass properties and their impact on design. Int. J. Rock Mech. \& Mining Sci., 35(1), pp. 63-68.

Hoek, E., P.G. Marinos, V.P. Marinos 2005: Characterization and engineering properties of tectonically undisturbed but lithologícally varied sedimentary rock masses. - Int. J. Rock Mech. \& Mining Sci., 42, pp. $277-285$.

Marinos, P., E. Hoek 2000: GSI: A geologically friendly tool for rock mass strength estimation. - In: Proc. GeoEng2000, Melbourne, Technomic Publ., Lancester, pp. 1422-1446.

Marinos, V., P. Marinos, E. Hoek 2005: The geological strength index: Applications and limitations. - Bull. Eng. Geol. Env., 64, pp. 55-65.

Palmström, A. 2001: Measurement and characterization of rock mass jointing. In-situ characterization of rock. - A.A. Balkema, p. 40.

Palmström, A., E. Broch 2006: Use and misuse of rock mass classification systems with particular reference to the Q-system. Tunnel. - Underg. Space Techn., 21, pp. 575-593.

Palmström, A. 2009: Technical note: Combining the RMR, Q, and RMi classification systems. Tunnel. Underg. Space Techn., 24(4), pp. 491-492.

Russo, G. 2009: A new rational method for calculating the GSI. Tunnel. - Underg. Space Techn., 24, pp. 103-111.

Singh, B., R.K. Goel 1999: Rock Mass Classification: A Practical Approach in Civil Engineering. - Elsevier, Amsterdam, 267 pp. 